\title{
Iodine Content of Various Meals Currently Consumed by Urban Japanese
}

\author{
Shinichiro Katamine, Yoneji MamiYa, Kunitoshi Sekimoto, \\ Nobuyuki Hoshino, Koji TotsuKa, ${ }^{1}$ Uhei NARUse, ${ }^{2}$ \\ Akira Watabe, ${ }^{3}$ Ryugo SugiYAmA, ${ }^{4}$ \\ and Masashige SUZUKI ${ }^{5}$ \\ ${ }^{1}$ Research Center, Nihon Nosan Kogyo K.K., \\ Hinode, Funabashi, Chiba 273, Japan \\ ${ }^{2}$ Faculty of Home Economics, Keihin Women's College, \\ Iwase, Kamakura, Kanagawa 247, Japan \\ ${ }^{3}$ Keio University Hospital, Shinano-machi, Shinjuku-ku, \\ Tokyo 160, Japan \\ ${ }^{4}$ Tokai University Hospital, Boseidai, Isehara, \\ Kanagawa 259-11, Japan \\ ${ }^{5}$ Laboratory of Biochemistry of Exercise and Nutrition, \\ Institute of Health and Sports Sciences, \\ University of Tsukuba, Sakura-mura, \\ Niihari-gun, Ibaraki 305, Japan \\ (Received March 24, 1986)
}

\begin{abstract}
Summary Various meals being currently consumed by urban Japanese were determined for iodine. The meal samples were collected in 1982 and 1984. The habitual daily home meals of 4 middle-aged Japanese living in urban areas contained 45-1,921 $\mu \mathrm{g}$ (mean; 362, 361, 429 and 1,023 $\mu \mathrm{g}$, respectively) of iodine per day. The regular meals served in two university hospitals contained 95-287 $\mu \mathrm{g}$ (mean; $195 \mu \mathrm{g}$ ) and 89-4,746 $\mu \mathrm{g}$ (mean; $1,290 \mu \mathrm{g}$ ) of iodine per day, respectively, and the diets for diabetes mellitus contained $59-144 \mu \mathrm{g}$ (mean; $96 \mu \mathrm{g}$ ) of iodine per day. In the daily meals containing iodine exceeding $c a .300 \mu \mathrm{g}$, some kinds of seaweeds and, in some cases, several foods containing a red food color with low iodine bioavailability, erythrosine, provided a large portion of iodine. The iodine contents of refectory meals in a university were $47-203 \mu \mathrm{g}$ (mean; $113 \mu \mathrm{g}$ ) per meal and those of lunches in two elementary schools were 25-31 $\mu \mathrm{g}$ (mean; $27 \mu \mathrm{g}$ ) and $18-43 \mu \mathrm{g}$ (mean; $36 \mu \mathrm{g}$ ) per lunch, respectively. These results suggest that the current daily iodine intake of urban Japanese is not great and that erythrosine elevates the iodine content of meals.
\end{abstract}

Key Words iodine, iodine intake, habitual home meal, university hospi-

\footnotetext{
${ }^{1}$ 片峯伸一郎，間宮米二，関本邦敏，星野信行，戸塚耕二， ${ }^{2}$ 成瀬宇平， ${ }^{3}$ 渡辺 昭,

${ }^{4}$ 杉山隆五, ${ }^{5}$ 鈴木正成
} 
tal meal, university refectory meal, school lunch, food color, erythrosine, Japanese

In 1960, Katsura and Nakamichi(1) estimated the iodine intake of the Japanese to be 500-1,000 $\mu$ g or more per day from the data on iodine levels in diets and in the urine of adult Japanese. Also, Koshiyama (2) reported a mean value of $706 \mu \mathrm{g}$ iodine excretion in the urine per day in 623 adult Japanese in 1962. These data therefore have led to a general concept that the iodine intake of the Japanese is adequate when compared with the recommended daily dietary allowance of $150 \mu \mathrm{g}$ iodine for adults as given by the U.S. National Research Council(3).

However, we recently examined the urinary iodine excretion of Japanese university students over 15 consecutive days and found a daily mean value of $357 \mu \mathrm{g}$ iodine (4), which is considerably lower than the value given by Koshiyama (2).

In the present study, we directly determined the iodine levels in meals currently being eaten by Japanese living in urban areas to obtain more information on the iodine intake of modern Japanese.

\section{MATERIALS AND METHODS}

Meal samples. Habitual home meals were prepared according to menus recorded by 4 middle-aged Japanese (35-45yr) living in urban areas near Tokyo, over 7 consecutive days in autumn, 1982. Regular meals and the diets for diabetes mellitus in a university hospital (Tokyo) were collected over 5 consecutive days in autumn, 1982, and regular meals in another university hospital (Kanagawa) over 10 consecutive days in summer, 1984. A one-day meal ready to eat was prepared by mixing the breakfast, lunch and supper of a particular day. The energy and protein levels of the one-day meals were respectively 1,260-2,470 kcal (mean; 1,800 kcal) and 41-98 $\mathrm{g}$ (mean; 67g) for the habitual home meals, 1,890-2,110 kcal (mean; $2,040 \mathrm{kcal}$ ) and $78-92 \mathrm{~g}$ (mean; $84 \mathrm{~g}$ ) for the university hospital regular meals collected in 1982, and 1,230-1,520 kcal (mean; 1,310 kcal) and 56-81 g (mean; $63 \mathrm{~g}$ ) for the university hospital diets for diabetes mellitus. University refectory meals were bought in 4 refectories of a university (Ibaraki) on a particular day in July, 1984. In two elementary schools located in urban areas (Kanagawa), school lunches were collected over 5 consecutive days in summer and autumn, respectively, 1984. The meal samples were homogenized thoroughly in a multi-blendor mill (Model BL-1, Nihon Seiki Co., Ltd., Tokyo) and then lyophilized.. Demineralized water was added to the samples with a low moisture content prior to homogenization.

Chemical analyses. Iodine in the lyophilized meal samples was determined by the modified method of Lauber (5) with the dry alkaline incineration of samples, as illustrated in Scheme 1. Standard KI solution containing 0, 25, 50, 100 or $200 \mathrm{ng}$ 
Table 1. Iodine contents of pooled one-day habitual home meals taken by several middle-aged Japanese living in urban areas.

The meal samples were prepared according to the menus used by middle-aged Japanese A, B, C and D. A one-day meal was prepared by mixing breakfast, lunch and supper ready to eat.

\begin{tabular}{ccccc}
\hline & \multicolumn{4}{c}{ Home } \\
\cline { 2 - 5 } Day & $\mathrm{A}$ & $\mathrm{B}$ & $\mathrm{C}$ \\
& \multicolumn{5}{c}{ Iodine content $(\mu \mathrm{g} /$ one-day meal $)$} \\
\hline 1 & $1,240^{\mathrm{a}}$ & 64 & 218 & $\mathrm{D}$ \\
2 & $1,921^{\mathrm{b}}$ & $879^{\mathrm{a}, \mathrm{c}}$ & 62 & 57 \\
3 & 45 & 163 & 119 & $1,561^{\mathrm{b}}$ \\
4 & $515^{\mathrm{e}}$ & 68 & $362^{\mathrm{e}}$ & $548^{\mathrm{a}}$ \\
5 & $858^{\mathrm{c}, \mathrm{d}}$ & 57 & 182 & $295^{\mathrm{e}}$ \\
6 & $916^{\mathrm{a}}$ & 58 & $1,098^{\mathrm{a}, \mathrm{c}, \mathrm{e}}$ & $296^{\mathrm{e}}$ \\
7 & $1,667^{\mathrm{b}}$ & $1,244^{\mathrm{a}}$ & $488^{\mathrm{a}}$ & 52 \\
\hline Mean & 1,023 & 362 & 361 & 429 \\
\hline
\end{tabular}

${ }^{a-e}$ In these meals, Vienna sausage (a), hijiki (b), wakame (c), canned cherries (d) and red-colored boiled fish-paste (e) were included.

Table 2. Iodine contents of pooled one-day regular meals and diets for diabetes of university hospitals.

A one-day meal was prepared by mixing breakfast, lunch and supper ready to eat. The 10 regular meals of B University hospital consisted of 3 low-iodine and 7 high-iodine meals.

\begin{tabular}{|c|c|c|c|c|}
\hline & \multirow{2}{*}{ Meals } & \multirow{2}{*}{$\begin{array}{l}\text { Number of } \\
\text { samples }\end{array}$} & \multicolumn{2}{|c|}{ Iodine content ( $\mu \mathrm{g} /$ one-day meal) } \\
\hline & & & Mean & Range \\
\hline \multirow[t]{3}{*}{ A } & University & & & \\
\hline & Regular & 5 & 195 & $95-287$ \\
\hline & For diabetes & 5 & 96 & $59-144$ \\
\hline \multirow[t]{4}{*}{ B } & University & & & \\
\hline & Regular & 10 & 1,290 & $89-4,746$ \\
\hline & (Low iodine) & (3) & $(107)$ & $(89-149)$ \\
\hline & (High iodine) & $(7)^{\mathrm{a}}$ & $(1,797)$ & $(455-4,746)$ \\
\hline
\end{tabular}

${ }^{a}$ These meals included one or two of the foods such as kombu, hijiki, wakame, canned cherries and red-colored boiled fish-paste.

\section{Daily habitual home and hospital meals}

Habitual home meals contained 45-1,921 $\mu \mathrm{g}$ of iodine per day, as summarized in Table 1. In home A, the highest mean value of $1,023 \mu \mathrm{g}$ of iodine was found, but 
in the other 3 homes mean values were 362,361 and $429 \mu \mathrm{g}$. The one-day meal samples, showing an iodine content of more than about $300 \mu \mathrm{g}$, included one or more of the red-colored Vienna sausage, canned cherries and boiled fish-paste, and seaweeds such as hijiki (Hizikia fusiformis) and wakame (Undaria pinnatifida). Table 2 shows the iodine contents of one-day regular meals and the diets for diabetes mellitus in two university hospitals. The regular meals of University A contained 95-287 $\mu \mathrm{g}$ (mean; $195 \mu \mathrm{g}$ ) of iodine, whereas those of University B contained 89$4,746 \mu \mathrm{g}$ (mean; $1,290 \mu \mathrm{g}$ ) of iodine per day. Out of the 10 regular meals of University B, 7 meal samples showed a high mean value of $1,797 \mu \mathrm{g}$ of iodine per day and included one or two of the red-colored canned cherries and boiled fishpaste, and seaweeds such as kombu (Laminaria japonica), hijiki and wakame. The iodine content of the diets for diabetes mellitus was 59-144 $\mu \mathrm{g}$ (mean; $96 \mu \mathrm{g}$ ) per day.

\section{University refectory meals and elementary school lunches}

As seen in Table 3, the mean iodine content of refectory meals of University C was $113 \mu \mathrm{g}(47-203 \mu \mathrm{g})$ per meal, of which $31-99 \mu \mathrm{g}$ was derived from the wakamemiso soup used in the meals. The lunches of Elementary Schools D and E gave mean iodine content values of $27 \mu \mathrm{g}(25-31 \mu \mathrm{g})$ and $36 \mu \mathrm{g}(18-43 \mu \mathrm{g})$ per lunch, respectively. Two hundred $\mathrm{ml}$ of milk was generally served for these lunches and the milk provided 15 and $24 \mu \mathrm{g}$ of iodine for Elementary School D and E lunches, respectively. Six brands of milk manufactured in Japan were also found to contain 15-29 $\mu \mathrm{g}$ (mean; $22.5 \mu \mathrm{g}$ ) of iodine per $200 \mathrm{ml}$.

\section{Erythrosine in meals}

Several meal samples, though they did not include seaweeds, showed a high iodine content over $c a$. $300 \mu \mathrm{g}$. Some red-colored foods such as Vienna sausage,

Table 3. Iodine contents of university refectory regular meals and elementary school lunches.

\begin{tabular}{|c|c|c|c|c|c|}
\hline \multirow[b]{2}{*}{ Meals } & \multirow[b]{2}{*}{$\begin{array}{c}\text { Number of } \\
\text { samples }\end{array}$} & \multicolumn{2}{|c|}{ Iodine content of meals } & \multicolumn{2}{|c|}{ Iodine derived from } \\
\hline & & Mean & $\begin{array}{l}\text { Range } \\
\text { eal) }\end{array}$ & $\begin{array}{c}\text { Wakame-miso } \\
\text { soup } \\
(\mu \mathrm{g} / \text { cup })\end{array}$ & $\begin{array}{c}\text { Milk } \\
(\mu \mathrm{g} / 200 \mathrm{ml})\end{array}$ \\
\hline $\begin{array}{l}\text { C University } \\
\text { refectory meals } \\
\text { D Elementary }\end{array}$ & 13 & 113 & $47-203$ & $31-99$ & \\
\hline $\begin{array}{l}\text { School lunches } \\
\text { E Elementary } \\
\text { School lunches }\end{array}$ & 5 & 27 & $25-31$ & & 15 \\
\hline
\end{tabular}

${ }^{\text {a }}$ One of the 5 meal samples did not include milk. 
Table 4. Iodine contents of several foods containing red food colors.

These foods were purchased from a supermarket.

\begin{tabular}{lccc}
\hline & \multicolumn{3}{c}{ Iodine content $(\mu \mathrm{g} / \mathrm{g})$} \\
\cline { 2 - 4 } & Whole & Colored portion & Casing portion \\
\hline Vienna sausage (A) & 45 & & 333 \\
Vienna sausage (B) & 3.2 & & \\
Vienna sausage (C) & 3.6 & & \\
Canned cherries & 113 & 44 \\
Red-colored & 8.0 & 4 \\
boiled fish-paste & & & \\
\hline
\end{tabular}

${ }^{a}$ The casing portion of Vienna sausage (A) and the colored portion of boiled fish-paste were also determined for iodine.

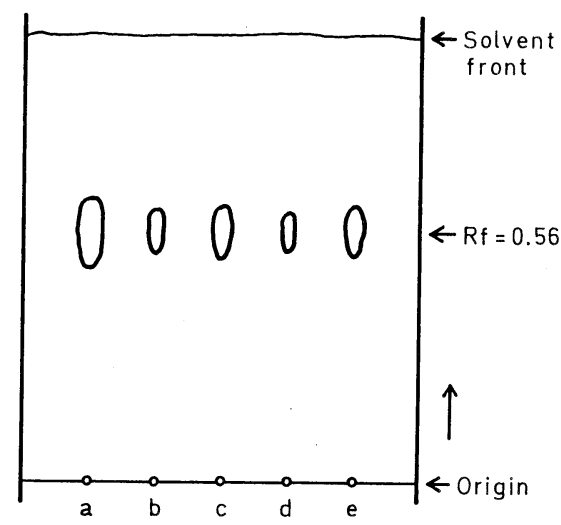

Fig. 2. Paper chromatogram of erythrosine extracted from several foods. a, erythrosine (standard); b, Vienna sausage(A); c, Vienna sausage(A) - casing portion; d, boiled fish-paste - red colored portion; e, canned cherries. Paper: Toyo No. 50 (Toyo Kagaku Sangyo Co., Ltd., Tokyo). Solvent system: $n$-BuOH-anhyd. EtOH$1 \% \mathrm{NH}_{4} \mathrm{OH}=6: 2: 3$.

canned cherries and boiled fish-paste were included in these meals. Since it was assumed that these red-colored foods might contain erythrosine (an iodine compound) as a red food color, they were subjected to the determination of iodine and the qualitative analysis for erythrosine. As shown in Table 4, one of 3 Vienna sausages as well as canned cherries contained fairly high amounts of iodine. The iodine content of the boiled fish-paste was not very high; however, its colored portion showed a high iodine content. Erythrosine was extracted from these high iodine-containing foods and identified by paper chromatography (Fig. 2). 


\section{DISCUSSION}

The pooled one-day habitual home and university hospital meals had a wide range of iodine content. It was also shown that some seaweeds, which are known to be a major source of iodine in Japanese meals $(1,7,8)$, and erythrosine are both contributive to the elevation of iodine content of meals. On the other hand, university refectory meals and elementary school lunches contained relatively low amounts of iodine. This was due to the inclusion of no or only a little seaweeds and erythrosine.

According to the National Nutrition Surveys of the Japanese in the years studied (9), the consumption of seaweeds per capita is lower in urban areas than in rural. Furthermore, although the total consumption of seaweeds per capita during the years is approximately the same as that in the 1960's $(9,10)$, the consumption of kombu per capita in urban communities has been reported in the Food Balance Sheet (11) to be decreasing whereas that of wakame to be increasing since the 1960's. Since kombu is well known to be highly superior to wakame as a source of iodine $(1,4,7)$, the dietary iodine intake of urban Japanese may be decreasing, and there might be a state of considerably low intake of iodine for people ingesting habitual meals free of high-iodine foods such as seaweeds.

The daily intake of iodine for adults in other countries has been presented in recent years; i.e., $696 \mu \mathrm{g}$ in the U.S.A. (12), $323 \mu \mathrm{g}$ in Great Britain (13), $210 \mu \mathrm{g}$ in The Netherlands (14), $340 \mu \mathrm{g}$ in Finland (15), $305 \mu \mathrm{g}$ in New Zealand (16), $446 \mu \mathrm{g}$ in Canada and $108 \mu \mathrm{g}$ in Yugoslavia(17). Seeing from the iodine contents of the various meals examined here and from our previous finding showing a mean daily urinary iodine excretion of $357 \mu \mathrm{g}$ for university students (4), the iodine intake of urban Japanese may be estimated to be comparable with those in other countries mentioned above and to be not as great as the $500-1,000 \mu \mathrm{g}$ or more reported in the 1960's (1). However, further broad and detailed investigation is needed to ascertain the iodine intake of modern average Japanese including people in rural and fishery areas.

In the estimation of dietary iodine intake, it seems to be of importance to take into consideration the bioavailability of iodine ingested, as Park et al. (12) have discussed. We therefore have studied the absorption and urinary excretion of iodine in rats and humans for some seaweeds, high-iodine eggs (18-20) and two red food colors, erythrosine and rose bengal which is also permitted in Japan. It was found that a high bioavailability of iodine was exerted for kombu and high-iodine eggs but not for the two red food colors. These data have been briefly presented (21-23) and detailed data will be published elswhere.

In conclusion, the present results suggest that the daily iodine intake of urban Japanese is relatively low and that erythrosine, a red food color with low iodine bioavailability, contributes to increasing the iodine level in meals.

The authors gratefully express their thanks to Mr. M. Oyaizu of Musashino Nutritionist Vol. 32, No. 5, 1986 
School for his kind preparation of habitual home meals, and also to Mrs. M. Iwasaki of Fukazawa Elementary School and Miss S. Ozawa of Sozen Elementary School for their courtesy in collection of school lunches. This work was presented at the 38th and 39th Annual Meeting of the Japanese Society of Nutrition and Food Sciences, Kyoto, May, 1984, and Tokyo, April, 1985, respectively.

\section{REFERENCES}

1) Katsura, E., and Nakamichi, R. (1960): The iodine intake of Japanese. Eiyo To Shokuryo (J. Jpn. Soc. Food Nutr.), 12, 345-347.

2) Koshiyama, K. (1962): Clinical studies on iodine metabolism and thyroid function by $\mathrm{I}^{131}$. Part 1. Age difference of thyroid function in normal subjects. Naika-hokan (Jpn. Arch. Int. Med.), 9, 381-392.

3) National Research Council (1980): Iodine, in Recommended Dietary Allowances, 9th Rev. Ed., National Academy of Sciences, Washington, D.C., pp. 147-151.

4) Suzuki, M., and Tamura, T. (1985): Iodine intake of Japanese male university students: Urinary iodine excretion of sedentary and physically active students and sweat iodine excretion during exercise. J. Nutr. Sci. Vitaminol., 31, 409-415.

5) Lauber, K (1975): Iodine determination in biological material. Kinetic measurement of the catalytic activity of iodine. Anal. Chem., 47, 769-771.

6) Pharmaceutical Society of Japan (1980): Food colors, in Standard Methods of Analysis for Hygienic Chemists-With Commentary, Kanehara Shuppan Co., Ltd., Tokyo, pp. 351-381.

7) Sekimoto, K., Hoshino, N., Totsuka, K., and Watabe, A., and Yamashita, T. (1983): Exudation of minerals from dried seaweeds during water immersion treatment. Nippon Eiyo Shokuryo Gakkaishi (J. Jpn. Soc. Nutr. Food Sci.), 36, 21-24.

8) Sekimoto, K., Endo, A., and Katamine, S. (1986): Comparison of extraction rates of minerals from Suboshi-, Haiboshi- and Enzo-wakame (Undaria pinnatifida) during water immersion treatment. Nippon Eiyo Shokuryo Gakkaishi (J. Jpn. Soc. Nutr. Food Sci.), 39, 67-70.

9) Public Health Bureau, Ministry of Health and Welfare of Japan (1984): National Nutrition Survey of Japanese in 1982, Daiichi Publishing Co., Ltd., Tokyo, pp. 52-57.

10) Public Health Bureau, Ministry of Health and Welfare of Japan (1973): National Nutrition Survey of Japanese in 1969, 1970 and 1971, Daiichi Publishing Co., Ltd., Tokyo, p. 316.

11) Research Division, Minister's Secretariat, Ministry of Agriculture, Forestry and Fisheries of Japan (1981): Food Balance Sheet in 1979, Association for Agricultural and Forestry Statistics, Tokyo, pp. 107-108.

12) Park, Y. K., Harland, B. F., Vanderveen, J. E., Shank, F. R., and Prosky, L. (1981): Estimation of dietary iodine intake of Americans in recent years. J. Am. Diet. Assoc., 79, 17-24.

13) Wenlock, R. W., Buss, D. H., Moxon, R. E., and Bunton, N. G. (1982): Trace nutrients. 4. Iodine in British food. Br. J. Nutr., 47, 381-390.

14) Van Dokkum, W., De Vos, R. H., Cloughley, F. A., Hulshof, K. F. A. M., Dukel, F., and Wijsman, J. A. (1982): Food additives and food components in total diets in the Netherlands. Br. J. Nutr., 48, 223-231.

15) Varo, P., Saari, E., Passo, A., and Koivistoinen, P. (1982): Iodine in finnish foods. Int. J. Vit. Nutr. Res., 52, 80-89. 
16) Cooper, G. J. S., Croxson, M. S., and Ibbertson, H. K. (1984): Iodine intake in an urban environment: A study of urine iodide excretion in Auckland. NZ Med. J., 97, $142-145$.

17) Bastomsky, C. H., Banovac, K., Skreb, F., and Sekso, M. (1979): Similar serum concentrations of thyroid hormones in two geographically separate populations on disparate iodine intake. Horm. Metab. Res., 11, 301-304.

18) Tanaami, S., Katamine, S., Hoshino, N., Totsuka, K., and Suzuki, M. (1985): Histopathological study on rats fed iodine-enriched eggs long-term (7 and 19 months). J. Nutr. Sci. Vitaminol., 31, 29-42.

19) Katamine, S., Hoshino, N., Totsuka, K., and Suzuki, M. (1985): Effects of the longterm (17-19 months) feeding of high-iodine eggs on lipid metabolism and thyroid function in rats. J. Nutr. Sci. Vitaminol., 31, 339-353.

20) Katamine, S., Tanaami, S., Mamiya, Y., Sekimoto, K., Hoshino, N., Totsuka, K., and Suzuki, M. (1985): Influences of feeding of high-iodine eggs on hypo- and hyperthyroid rats. J. Nutr. Sci. Vitaminol., 31, 541-551.

21) Mamiya, Y., Katamine, S., Sekimoto, K., Hoshino, N., Totsuka, K., and Suzuki, M. (1984): Absorption of iodine in foods and its urinary excretion. Iodine-enriched egg and seaweeds. The 38th Annual Meeting of Jpn. Soc. Nutr. Food Sci. (Abstract No. 3D-1a), Kyoto, May.

22) Katamine, S., Sekimoto, K., Hoshino, N., Totsuka, K., and Suzuki, M. (1986): Absorption and urinary excretion of iodine in two food colors, erythrosine and rose bengal, in rats. The 40th Annual Meeting of Jpn. Soc. Nutr. Food Sci. (Abstract No. 2A-7a), Nagoya, May.

23) Katamine, S., Sekimoto, K., Hoshino, N., Totsuka, K., and Suzuki, M. (1986): Absorption and urinary excretion of iodine in two food colors, erythrosine and rose bengal, in humans. The 40th Annual Meeting of Jpn. Soc. Nutr. Food Sci. (Abstract No. 2A-8a), Nagoya, May. 